\title{
Increased Erythrocyte Cation Permeability in Thalassemia and Conditions of Marrow Stress
}

\author{
J. S. WILEY, Department of Haematology, Austin Hospital, Melbourne, 3084, Australia; \\ Hematology-Oncology Section, Department of Medicine, Hospital of the \\ University of Pennsylvania, Philadelphia, Pennsylvania 19104
}

\begin{abstract}
A B S T RACT Calcium and sodium permeability of erythrocytes from patients with untransfused $\alpha$ - or $\beta$ thalassemia major has been studied and compared to mature erythrocytes or control cells with comparable reticulocytosis. Isotopic $\mathrm{Na}^{+}$influx was increased a mean fourfold greater than normals and threefold greater than reticulocyte rich control. Passive net leak of $\mathrm{Na}^{+}$into thalassemic cells incubated with ouabain was also increased corresponding to their greater ${ }^{22} \mathrm{Na}^{+}$ influx. Erythrocyte $\mathrm{Na}^{+}$and $\mathrm{K}^{+}$concentrations and cell water content per unit volume of cells were normal. Quantitation of active cation pumps in the cell membrane by the technique of $\left[{ }^{3} \mathrm{H}\right]$ ouabain binding showed a 2.6- to 9.9-fold increase above normal. Inward $\mathrm{Ca}^{2+}$ movement was studied in cells with absent $\mathrm{Ca}^{2+}$ pumping produced by depletion of either ATP or $\mathrm{Mg}^{2+}$-ions. Calcium uptake by ATP depleted thalassemic cells was increased 12 -fold above normals and 3.6-fold above reticulocyte-rich controls. The $\mathrm{Ca}^{2+}$ uptake by $\mathrm{Mg}^{2+}$-depleted thalassemic cells was also increased above normal confirming that erythrocyte $\mathrm{Ca}^{2+}$ permeability is increased in this disease. Osmotic fragility measurements show that the surface area to volume ratio of thalassemic erythrocytes was increased by 15 to $25 \%$ above mature erythrocytes. The increased passive cation permeability of thalassemic erythrocytes cannot be explained by either reticulocytosis or an increased surface area to volume ratio of these cells. Moreover, erythrocyte $\mathrm{Na}^{+}$and $\mathrm{Ca}^{2+}$ influxes in congenital dyserythropoietic anemia (CDA type 2) were increased 2- and 14-fold, respectively, above normal. The increased cation fluxes and cation pump numbers in thalassemic and congenital dyserythropoietic anemia erythrocytes are consistent with the hypothesis of membrane immaturity arising from rapid marrow transit times, a concept previously advanced to explain the persistence of i-antigen on these cells.
\end{abstract}

Received for publication 24 March 1980 and in revised form 5 November 1980.

\section{INTRODUCTION}

Thalassemia is a heterogeneous group of inherited diseases in which erythroid cells fail to synthesize the globin chains of hemoglobin. A number of erythrocyte membrane abnormalities have been documented in the thalassemic syndromes. First, the osmotic fragility is reduced so that the cells have an increased surface area to volume ratio. $(1,2)$. Second, the amount of i-antigen is increased on the circulating erythrocytes and the persistence of this fetal antigen has led to the suggestion that the erythrocyte membrane is immature $(3,4)$. Finally permeability studies have established that $\mathbf{K}^{+}$ fluxes are increased both into and out of the erythrocyte although the intracellular $\mathrm{K}^{+}$concentrations are unknown (5). In this study the $\mathrm{Na}^{+}$and $\mathrm{Ca}^{2+}$ permeability as well as the binding of $\left[{ }^{3} \mathrm{H}\right]$ ouabain to erythrocytes has been measured in patients with both $\alpha$ - and $\beta$ thalassemia major.

\section{METHODS}

Patients. F.L. was a black female with $\beta$-thalassemia major who had been splenectomized at the age of $8 \mathrm{yr}$ with a decrease in her transfusion requirements. Blood for this study was always drawn $10 \mathrm{wk}$ after preceding transfusions when her only medication was folic acid. An increased titer of i-antigen was present on her erythrocytes and numerous erythroblasts were present in the peripheral blood. (Table I). Four other patients with $\beta$-thalassemia major have been described previously, all had intact spleens, and none were transfusion dependent $(6,7)$. A.B. was an Italian girl diagnosed as $\beta$ thalassemia major in a family study after an older sibling was found to have the same disease. Hepatosplenomegaly was present and both parents were shown to have $\beta$-thalassemia minor. M.L. was a Chinese female student with hemoglobin $\mathrm{H}$ disease and splenomegaly who was asymptomatic at the time of study. C.C. was a Greek Cypriot woman with asymptomatic hemoglobin $\mathrm{H}$ disease and splenomegaly. An increased i-antigen was found on her erythrocytes. G.K. was a consanguinous white male with congenital dyserythropoietic anemia (type 2) with splenomegaly who was not transfusion dependent (Table I). His erythrocytes carried increased amount of $i$-antigen and $30 \%$ of the marrow erythroblasts were binucleate (8). The two patients with hereditary persistence 
TABLE I

Hematological Parameters in Patients Studied

\begin{tabular}{|c|c|c|c|c|c|c|c|c|c|}
\hline & & & \multirow[b]{2}{*}{ Hemoglobin } & \multirow[b]{2}{*}{ Retics } & \multirow[b]{2}{*}{ MCV } & \multicolumn{3}{|c|}{ Percent hemoglobin } & \multirow[b]{2}{*}{ Reference } \\
\hline & & & & & & $\mathrm{A}_{2}$ & $\mathbf{F}$ & $\mathbf{H}$ & \\
\hline & & & $g / d l$ & $\%$ & $f t$ & & & & \\
\hline F.L.* & 19 & Black & 7.3 & 4.9 & 74 & 6.0 & 30 & - & - \\
\hline K.B. & 18 & White & 8.0 & 5.6 & 60 & 3.9 & 11.8 & - & 6 \\
\hline C.B. & 12 & White & 6.9 & 6.0 & 56 & 4.8 & 6.2 & - & 6 \\
\hline H.H. & 13 & Black & 10.0 & 2.5 & 58 & 7.5 & 45.7 & - & 7 \\
\hline D.H. & 10 & Black & 7.8 & 3.2 & 58 & 6.5 & 43.5 & - & 7 \\
\hline A.B. & 7 & White & 9.7 & 3.5 & 71 & 6.0 & 63 & - & - \\
\hline M.L. & 26 & Chinese & 9.8 & 2.5 & 60 & - & - & 8 & - \\
\hline C.C. & 50 & White & 8.8 & 3.1 & 63 & - & - & 11 & - \\
\hline G.K. & 41 & White & 9.5 & 4.1 & 113 & 2.0 & 1.9 & - & 8 \\
\hline
\end{tabular}

* Patient splenectomized and washed erythrocyte suspensions contained 2-4\% erythroblasts. This patient was studied $10 \mathrm{wk}$ after preceding transfusion. No other patients were receiving transfusions.

of i-antigen were both hematologically normal although both possessed anti-I antibody. The control suspensions with $4.2 \%$ reticulocytes were obtained from a patient with autoimmune hemolytic anemia on no medication at the time of study.

Serology. The strength of i-antigen was quantitated by scoring erythrocyte agglutination in tubes containing doubling dilutions of two different anti-i antisera and comparing with pooled adult and pooled cord erythrocytes (9).

Permeability studies. Venous blood was drawn into heparin anticoagulant and erythrocytes separated from buffy coat by thrice washing at $4^{\circ} \mathrm{C}$ in a saline medium of composition of $145 \mathrm{mM} \mathrm{NaCl}, 5 \mathrm{mM} \mathrm{KCl}$, and $20 \mathrm{mM}$ imidazole $\mathrm{Cl}, \mathrm{pH}$ 7.5. The reticulocyte counts shown in Table I as well as osmotic fragility measurements were performed on the washed erythrocytes by standard techniques (2). Erythrocyte $\mathrm{Na}^{+}, \mathrm{K}^{+}$, and water content, as well as isotopic sodium influx, and $\left[{ }^{3} \mathrm{H}\right]$ ouabain binding to erythrocytes were measured as described previously $(10,11)$. The net $\mathrm{Na}^{+}$uptake of cells was measured over a $6-\mathrm{h}$ incubation at $37^{\circ} \mathrm{C}$ with $5 \mathrm{mM}$ glucose and $0.1 \mathrm{mM}$ ouabain. Aliquots of the cell suspension were taken at $0,2,4$, and $6 \mathrm{~h}$, the cells rapidly washed fourfold in ice-cold $110 \mathrm{mM}-\mathrm{MgCl}_{2}$, the cells were hemolyzed in $0.01 \mathrm{~N}-\mathrm{NH}_{4} \mathrm{OH}$ and $\mathrm{Na}^{+}$analyzed by flame photometry (11).

Calcium uptake. Washed erythrocytes were depleted of ATP by preincubation for $90 \mathrm{~min}$ in medium plus $1 \mathrm{mM}$ iodoacetate and $10 \mathrm{mM}$ inosine $(10,12)$. The erythrocytes were then washed twice and added to prewarmed media of composition $145 \mathrm{mM} \mathrm{NaCl}, 5 \mathrm{mM} \mathrm{KCl}, 20 \mathrm{mM}$ imidazole $\mathrm{Cl}, \mathrm{pH}$ 7.5 plus $1.5 \mathrm{mM}^{45} \mathrm{CaCl}_{2}(1 \mu \mathrm{Ci} / \mathrm{ml})$. Samples were taken after 15 min and after $1,2,3$, and $4 \mathrm{~h}$, and washed four times in cold $150 \mathrm{mM} \mathrm{NaCl}$. Each cell pellet was hemolyzed in 0.01 $\mathrm{N} \mathrm{NH}_{4} \mathrm{OH}$, and part of the hemolysate was deproteinized with $6 \%\left(\mathrm{wt} / \mathrm{vol}\right.$ ) perchloric acid and ${ }^{45} \mathrm{Ca}^{2+}$ in the supernate was measured by liquid scintillation counting. To convert the uptake of radioactive calcium from nanomoles per micromole $\mathrm{Hb}$ into nanomoles per milliliter cells, the mean corpuscular hemoglobin concentration was measured in each experiment both for abnormal and normal cells.

Washed erythrocytes were depleted of $\mathrm{Mg}^{2+}$ by a $37^{\circ} \mathrm{C}$ preincubation in the dark for $2 \mathrm{~h}$ at $2 \%$ hematocrit in the above washing medium plus $10 \mathrm{mM}$ glucose, $2 \mathrm{mM}$ EDTA, and 17.5 $\mathrm{nmol} / \mathrm{ml}$ cells of ionophore A23187 (Eli Lilly \& Co., Indianapolis, Ind. (13). The erythrocytes were then washed five times at $37^{\circ} \mathrm{C}$ in saline medium plus $2 \mathrm{mM}$ EDTA, $10 \mathrm{mM}$ glucose, and $4 \%$ bovine serum albumin (fraction V, Sigma Chemical Co., St. Louis, Mo.). They were then washed four more times at room temperature in a medium comprising $145 \mathrm{mM} \mathrm{NaCl}$, $5 \mathrm{mM} \mathrm{KCl}$, and $20 \mathrm{mM}$ imidazole, $\mathrm{pH}$ 7.4. The internal $\mathrm{Mg}^{2+}$ concentration was determined by atomic absorption spectrophotometry and was within the range of 0.02 to $0.05 \mu \mathrm{mol}$ $\mathrm{Mg}^{2+} / \mathrm{ml}$ cells. ${ }^{45} \mathrm{Ca}^{2+}$ uptake was measured on the washed, $\mathrm{Mg}^{2+}$-depleted erythrocytes as described above except for the addition of $5 \mathrm{mM}$ inosine to the ${ }^{45} \mathrm{Ca}^{2+}$ containing medium.

Statistics. Mean values $\pm 1 \mathrm{SD}$ are shown and differences between sample means analyzed by a $t$ test.

\section{RESULTS}

Isotopic and net sodium influx. Unidirectional ${ }^{22} \mathrm{Na}^{+}$influx into erythrocytes from six patients with $\beta$-thalassemia major was increased three- to eightfold above the normal value. Five of these influx values fell within the narrow range of 5.4 to $8.4 \mu \mathrm{eq} / \mathrm{ml}$ cells per $\mathrm{h}$, whereas the highest value of $17.0 \mu \mathrm{eq} / \mathrm{ml}$ cells per $\mathrm{h}$ was for the patient with $4 \%$ circulating erythroblasts following a splenectomy. Two patients with hemoglobin $\mathrm{H}$ disease ( $\alpha$-thalassemia) showed an approximate twofold increase in erythrocyte ${ }^{22} \mathrm{Na}^{+}$influx (Table II). The mean influx for all thalassemics, even excluding the patient postsplenectomy was significantly greater than the normal mean of $2.0 \pm 0.2 \mu \mathrm{eq} / \mathrm{ml}$ cells per $\mathrm{h}$ $(P<0.001)$. The inhibition of ${ }^{22} \mathrm{Na}^{+}$influx by the diuretic furosemide ( $1 \mathrm{mM}$ ) was 0.3 to $0.6 \mu \mathrm{eq} / \mathrm{ml}$ cells per $h$, a decrement that is not different to that observed in normal erythrocytes. Control erythrocytes, with comparable reticulocytosis $(2.5$ to $6.0 \%)$ had a total ${ }^{22} \mathrm{Na}^{+}$ influx between 2.1 and $2.8 \mu \mathrm{eq} / \mathrm{ml}$ cells per $\mathrm{h}$.

Isotopic ${ }^{22} \mathrm{Na}$ entry into cells occurs not only by net downhill movement of this cation ("passive leak") but also by a carrier which mediates $\mathrm{Na}-\mathrm{Na}$ exchange diffusion (14). The passive $\mathrm{Na}^{+}$leak was measured by the net gain of $\mathrm{Na}^{+}$by cells incubated with ouabain 
TABLE II

Cation Concentrations, Sodium Influx and Ouabain Binding in Erythrocytes

\begin{tabular}{|c|c|c|c|c|}
\hline & \multicolumn{2}{|c|}{ Erythrocytes } & \multirow[b]{2}{*}{$\mathrm{Na}^{+}$influx } & \multirow{2}{*}{$\begin{array}{l}\text { Maximum } \\
\text { ouabain } \\
\text { binding sites }\end{array}$} \\
\hline & $\mathrm{Na}^{+}$ & $\mathbf{K}^{+}$ & & \\
\hline & \multicolumn{2}{|c|}{ meq/ml cells } & $\begin{array}{l}\text { Meq/ml cells } \\
\quad \text { per } h\end{array}$ & molecules/cell \\
\hline \multicolumn{5}{|l|}{$\beta$-Thalassemia } \\
\hline F.L. & 13.1 & 103 & 17.0 & 1,275 \\
\hline K.B. & 6.2 & 107 & 5.8 & 2,098 \\
\hline C.B. & - & - & 8.4 & 3,594 \\
\hline H.H. & 9.8 & 103 & 7.1 & 961 \\
\hline D.H. & 6.7 & 102 & 6.2 & - \\
\hline A.B. & 4.7 & 93 & 5.4 & - \\
\hline \multicolumn{5}{|l|}{$\alpha$-Thalassemia } \\
\hline M.L. & 6.7 & 111 & 4.2 & - \\
\hline C.C. & 9.0 & 110 & 3.5 & - \\
\hline $\begin{array}{l}\text { Mean for all } \\
\text { thalassemia }\end{array}$ & 8.0 & 104 & $7.2^{*}$ & $1,982^{*}$ \\
\hline $\begin{array}{l}\text { Congenital dys- } \\
\text { erythropoi- } \\
\text { etic anemia }\end{array}$ & & & & \\
\hline G.K. & 9.4 & 102 & 4.0 & - \\
\hline \multicolumn{5}{|l|}{$\begin{array}{l}\text { Reticulocyte-rich } \\
(4.2 \%) \text { control }\end{array}$} \\
\hline J.B. & - & - & 2.8 & 811 \\
\hline Normals & 7.9 & 99 & 2.0 & 362 \\
\hline SD & \pm 1.5 & \pm 5 & \pm 0.2 & \pm 69 \\
\hline$n$ & 27 & 27 & 24 & 7 \\
\hline
\end{tabular}

* Significantly increased above normal mean, $P<0.001$.

to inhibit active cation transport. Erythrocytes from two patients with either $\alpha$-or $\beta$-thalassemia (C.C. and A.B.) gained $\mathrm{Na}^{+}$during a 6 -h incubation at mean rates of 2.25 and $1.7 \mu \mathrm{eq} / \mathrm{ml}$ cells per $\mathrm{h}$, respectively, compared with $0.85 \mu \mathrm{eq} / \mathrm{ml}$ cells per $\mathrm{h}$ for normals (Fig. 1). Control erythrocytes from a patient with reticulocytosis of $4.7 \%$ following acute blood loss were incubated for $6 \mathrm{~h}$ with ouabain and gained $\mathrm{Na}^{+}$at a mean rate of $0.95 \mu \mathrm{eq} / \mathrm{ml}$ cells per $\mathrm{h}$.

Intracellular cation and water contents. Thalassemic erythrocytes had a normal concentration of $\mathrm{Na}^{+}$ and $\mathrm{K}^{+}$expressed per unit volume of erythrocytes and although there was a slight increase in erythrocyte $\mathrm{Na}^{+}$ in the patient with circulating erythroblasts the mean cell $\mathrm{Na}^{+}$for the entire group did not differ significantly from normal (Table II). Erythrocyte water content was also normal. One patient with $\beta$-thalassemia had 654 $\mathrm{mg} / \mathrm{g}$, two patients with $\alpha$-thalassemia 652 and 665 $\mathrm{mg} / \mathrm{g}$, respectively, while normal water content was $658 \pm 6 \mathrm{mg} / \mathrm{g}$ wet wt cells (11).

$\left[{ }^{3} \mathrm{H}\right]$ ouabain binding. Thalassemic erythrocytes bound more $\left[{ }^{3} \mathrm{H}\right]$ ouabain than normal erythrocytes, by a factor of 2.6- to 9.9-fold (Table II). This increase in ouabain binding was even greater if values were ex-

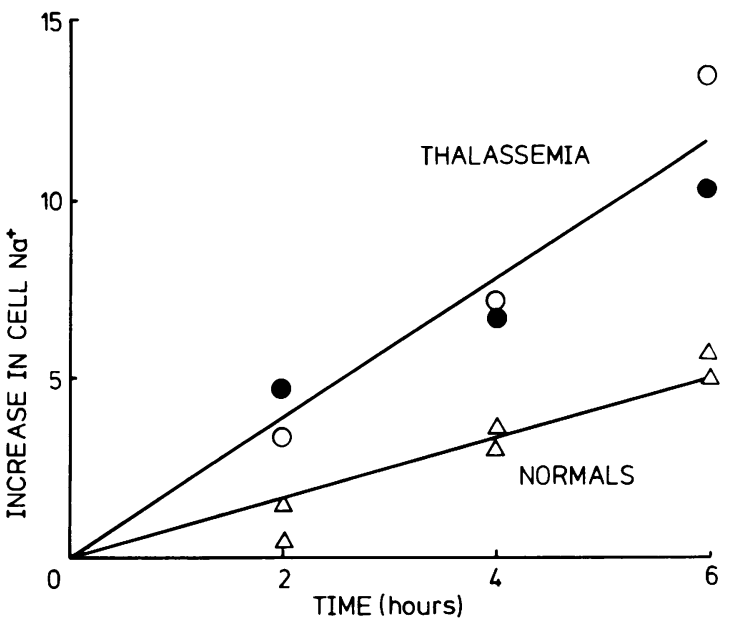

FIGURE 1 Net $\mathrm{Na}^{+}$uptake by thalassemic erythrocytes in the presence of ouabain. Fresh cells were incubated at $37^{\circ} \mathrm{C}$ in a saline medium containing glucose plus $0.1 \mathrm{mM}$ ouabain. The initial cell $\mathrm{Na}^{+}$concentration of 5.9 to $8.8 \mu \mathrm{eq} / \mathrm{ml}$ cells remained constant in a parallel incubation without ouabain. $\beta$-thalassemia $(O)$ and $\alpha$-thalassemia $(O)$ suspensions contained 3.0 and $2.9 \%$ reticulocytes, respectively. The net $\mathrm{Na}^{+}$ uptakes for two normal subjects $(\triangle)$ occurs at a rate similar to published values (Fig. 4, 15).

pressed in sites per $\mathrm{ml}$ cells rather than sites per cell. The relationship between maximum $\left[{ }^{3} \mathrm{H}\right]$ ouabain binding and reticulocyte numbers suggests a value of $500-800$ sites per cell in suspensions with $3-6 \%$ reticulocytes (10). Thus ouabain-binding sites on thalassemic cells were greater than expected for the percent reticulocytes present.

Calcium influx. Thalassemic erythrocytes showed a large increase in passive $\mathrm{Ca}^{2+}$ uptake, measured in cells depleted of ATP to inhibit the outward pumping of $\mathrm{Ca}^{2+}$ ions (12). The increase in $\mathrm{Ca}^{2+}$ uptake ranged from 6- to 15-fold (mean 12-fold) above the values for normal erythrocytes, and was observed with $\alpha$ - as well as $\beta$-thalassemic cells (Fig. 2). In one patient with $\alpha$ thalassemia (C.C.) the erythrocytes were depleted of ATP in paired flasks by two different combinations of inhibitors, namely iodoacetate plus inosine or iodoacetamide plus inosine. Subsequent uptake of ${ }^{45} \mathrm{Ca}$ by cells depleted in these two ways was identical and both were elevated sevenfold above normal. (Isotopic $\mathrm{Na}^{+}$influx in either the ATP-depleted cells or the $\mathrm{Mg}^{2+}$-depleted cells were never increased above values for ATP-rich cells.) Reticulocytes also have a $\mathrm{Ca}^{2+}$ permeability that is greater than that of mature erythrocytes (10). However, $\mathrm{Ca}^{2+}$ uptake into control cells with $4.2 \%$ reticulocytosis was only 3.7-fold above normal values (Fig. 2). Thus the large $\mathrm{Ca}^{2+}$ uptake by thalassemic erythrocytes is only partly explained by the mild reticulocytosis.

The passive uptake of $\mathrm{Ca}^{2+}$ was also measured in cells depleted of $\mathrm{Mg}^{2+}$ by ionophore (13) a procedure which 


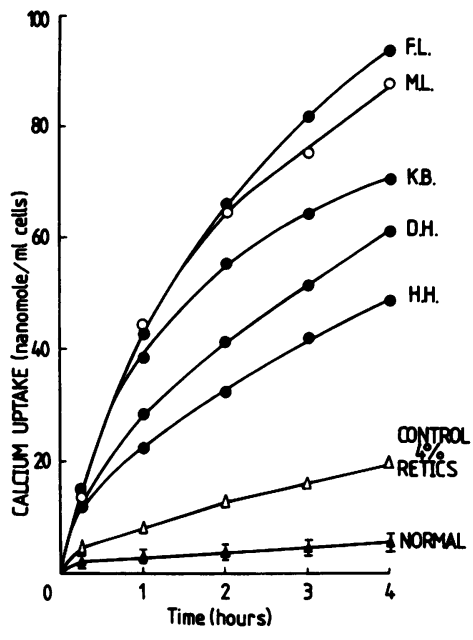

FIGURE 2 Calcium uptake by thalassemic erythrocytes. Cells were depleted of ATP and incubated at $37^{\circ} \mathrm{C}$ in a saline medium containing $1.5 \mathrm{mM}{ }^{45} \mathrm{CaCl}_{2}$. $\beta$-thalassemia $(O)$ and $\alpha$-thalassemia $(O)$ suspensions contained $2.5-6.0 \%$ reticulocytes, while the control $(\Delta)$ from a patient with autoimmune hemolytic anemia contained $4.2 \%$ reticulocytes. Values for normal erythrocytes $(\Delta)$ were from 14 normal donors and bars show \pm 1 SD.

inhibits the outward extrusion of $\mathrm{Ca}^{2+}$ ions by removal of a different cofactor for the pump. The $\mathrm{Ca}^{2+}$ uptake of $\mathrm{Mg}^{2+}$-depleted cells was $\sim 70 \%$ the value for ATPdepleted cells in all experiments with thalassemic and normal subjects. The marked difference between normal and thalassemic erythrocytes was still observed since $\mathrm{Ca}^{2+}$ uptake by the $\mathrm{Mg}^{2+}$-depleted cells from patient C.C. was increased by a factor of sixfold over normal (Table III). No increase in isotopic $\mathrm{Na}^{+}$influx into $\mathrm{Mg}^{2+}$-depleted cells was found so that the depletion procedure did not perturb the passive cation permeability.

Osmotic fragility in thalassemia. Mean osmotic fragility for three patients with thalassemia were 0.31 , 0.33 , and $0.34 \mathrm{~g} \mathrm{NaCl} / \mathrm{dl}$ compared with a normal range of 0.40 to $0.44 \mathrm{~g} \mathrm{NaCl} / \mathrm{dl}$. Thus thalassemic erythrocytes have a $15-25 \%$ increase in their surface area to volume ratio.

Congenital dyserythropoietic anemia (CDA). ${ }^{1}$ Erythrocytes from a patient with CDA Type 2 also demonstrated an increased $\mathrm{Na}^{+}$and $\mathrm{Ca}^{2+}$ permeability that was greater than expected for the $4.1 \%$ reticulocytes present. Sodium influx was twofold normal (Table II), the intracellular $\mathrm{Na}^{+}$and $\mathrm{K}^{+}$concentrations were both normal and $\mathrm{Ca}^{2+}$ uptake was increased to the same extent as for thalassemic cells and reached $78 \mathrm{nmol} / \mathrm{ml}$ cells by $4 \mathrm{~h}$, which is fourfold greater than the reticulocyte-rich control.

\footnotetext{
${ }^{1}$ Abbreviations used in this paper: CDA, congenital dyserythropoietic anemia.
}

TABLE III

Calcium Uptake by Erythrocytes Depleted Either of ATP or $\mathrm{Mg}^{2+}$-Ions

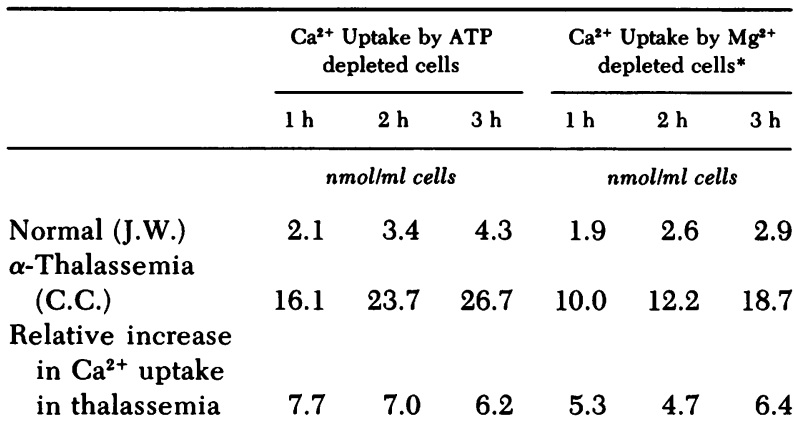

* Normal and thalassemic erythrocytes were preincubated with the ionophore A23187 to deplete $\mathrm{Mg}^{2+}$ from $1.96-1.98$ $\mu \mathrm{mol} / \mathrm{ml}$ cells down to 0.034 and $0.052 \mu \mathrm{mol} / \mathrm{ml}$ cells, respectively. Reticulocyte count of the thalassemic cells was $1.2 \%$ after the washing prior to depletion.

Hereditary persistence of $i$-antigen. Cation fluxes were also measured in erythrocytes from two subjects with the rare anomaly of hereditary persistence of $i$ antigen (16). Sodium influx (1.9 and $2.0 \mu \mathrm{eq} / \mathrm{ml}$ cells per $\mathrm{h}$ ), and erythrocyte $\mathrm{Na}^{+}$and $\mathrm{K}^{+}$concentrations of 8.8 and $103 \mu \mathrm{eq} / \mathrm{ml}$ cells, respectively, were all normal. Moreover $\mathrm{Ca}^{2+}$ uptakes by ATP-depleted cells from the two subjects ( 5.2 and $6.8 \mathrm{nmol} / \mathrm{ml}$ cells per $4 \mathrm{~h}$ ) were also within the range for normal mature erythrocytes $(5.4 \pm 1.5 \mathrm{nmol} / \mathrm{ml}$ cells per $4 \mathrm{~h})$.

\section{DISCUSSION}

The major finding is that thalassemic erythrocytes have a 4- and 12-fold increase in passive permeability to $\mathrm{Na}^{+}$ and $\mathrm{Ca}^{2+}$, respectively, as well as a similar increase in the number of sodium pumps per cell. Despite the substantial increase in $\mathrm{Na}^{+}$influx, intracellular $\mathrm{Na}^{+}$and $\mathrm{K}^{+}$ concentrations were normal when expressed either per unit volume of cells or per unit of cell water. Clearly the increment in cation pumps was sufficient to compensate fully for the greater $\mathrm{Na}^{+}$influx. Erythrocyte $\mathrm{K}^{+}$fluxes, both influx and efflux are also known to be increased in thalassemia but although passive $\mathrm{K}^{+}$loss may be as much as eightfold normal, active $\mathrm{K}^{+}$influx is sufficient to maintain the initial $\mathrm{K}^{+}$concentration (5). In mature erythrocytes passive $\mathrm{Na}^{+}$and $\mathrm{K}^{+}$fluxes are partly mediated by a $(\mathrm{Na}+\mathrm{K})$ cotransport system that can be inhibited by the diuretic, furosemide (17). Measurement of the furosemide sensitive component of $\mathrm{Na}^{+}$ influx in thalassemic erythrocytes showed it was normal in magnitude. A portion of the isotopic $\mathrm{Na}$ fluxes occurs by $\mathrm{Na}^{+}$exchange diffusion via a carrier that can also allow $\mathrm{Li}-\mathrm{Na}$ countertransport (14). Taken together $\mathrm{Na}^{+}$ exchange diffusion and $(\mathrm{Na}+\mathrm{K})$ cotransport account for some $40 \%$ of isotopic ${ }^{22} \mathrm{Na}$ influx in mature erythrocytes while the remainder is passive net leak. The net 
leak of $\mathrm{Na}^{+}$into thalassemic erythrocytes from two patients was increased 2.3-fold above normal, whereas the same two patients had a corresponding 1.8- to 2.7-fold increase in erythrocyte ${ }^{22} \mathrm{Na}$ influx. Thus erythrocyte $\mathrm{Na}^{+}$permeability is increased in thalassemia major when it is measured either isotopically or by flame photometry.

Calcium uptake in thalassemic erythrocytes was greatly increased by 12 -fold normal, although the relative increase was only 3.6 -fold when compared with the control reticulocyte-rich cells. Calcium uptake was first measured in ATP-depleted cells, a condition which selectively inactivates the outward pumping of $\mathrm{Ca}^{2+}$. ions (12). Thalassemic cells pretreated with two different metabolic inhibitors (iodoacetate and iodoacetamide) each gave the same value for the subsequent uptake of $\mathrm{Ca}^{2+}$ and this suggests that $\mathrm{Ca}^{2+}$ entry resulted from ATP depletion and not from a membrane-perturbing effect of the inhibitor (10). The uptake of $\mathrm{Ca}^{2+}$ was then measured in cells depleted of $\mathrm{Mg}^{2+}$ since removal of this cation cofactor will also inhibit the calcium pump. $\mathrm{Mg}^{2+}$-depleted cells did take up $\mathrm{Ca}^{2+}$ although the absolute uptake values were only $70 \%$ of that observed for ATP-depleted cells incubated in parallel flasks (Table III). Perhaps the lower $\mathrm{Ca}^{2+}$ accumulation by $\mathrm{Mg}^{2+}$-depleted cells may be due to slight residual activity of the calcium pump since it was not possible to reduce $\mathrm{Mg}^{2+}$ below $0.02-0.05 \mu \mathrm{mol} / \mathrm{ml}$ cells. The important finding was that $\mathrm{Mg}^{2+}$-depleted thalassemic erythrocytes had a marked increase in $\mathrm{Ca}^{2+}$ uptake of the same relative amount as found previously for ATP-depleted cells i.e., sixfold above normal for patient C.C. In contrast neither ATP-depletion nor $\mathrm{Mg}^{2+}$ depletion increased the isotopic $\mathrm{Na}^{+}$influx of normal or thalassemic erythrocytes. The above results make it likely that both depletion procedures inhibit the $\mathrm{Ca}^{2+}$ pump without increasing passive cation permeability and that the $\mathrm{Ca}^{2+}$ uptake by depleted cells reflects the true passive $\mathrm{Ca}^{2+}$ permeability of the intact nondepleted erythrocyte. The implications of this increased $\mathrm{Ca}^{2+}$ permeability are not clear. The capacity of the erythrocyte for outward $\mathrm{Ca}^{2+}$ pumping is very large (18-21) so that an increased $\mathrm{Ca}^{2+}$ leakiness of the thalassemic erythrocyte is likely to produce very little $\mathrm{Ca}^{2+}$ accumulation although even a slight increase may be significant in the etiology of the short erythrocyte survival found in this syndrome (22-24).

Why do thalassemic cells have a many fold increase in cation permeability? First, the permeability increase cannot be ascribed to an increased surface area to volume ratio of thalassemic cells, since this ratio was only increased by 15 to $25 \%$. Second, it is clear that the increased permeability is not an immediate and direct consequence of $\mathrm{i}$-antigen that is known to be present in thalassemia $(3,4)$, because erythrocytes from two persons with hereditary persistence of i-antigen had normal cation permeability. However the rare anomaly of persistent i-antigen has a different genetic basis to thalassemia since in the former the $\mathrm{i}$-antigen persists in the absence of I-antigen and moreover these persons are hematologically normal. Third, all the thalassemic patients who were studied showed 2.5 to $6.0 \%$ reticulocytosis but these cells were insufficient in numbers to account for the many fold increase in either cation permeability or cation pump numbers.

Other explanations must be considered for the increased $\mathrm{Na}^{+}$and $\mathrm{Ca}^{2+}$ permeability in thalassemia. A previous study has suggested that the increased $\mathrm{K}^{+}$ permeability observed in thalassemic erythrocytes results from the interaction of free globin chains with the membrane (5). However, it is unlikely that free globin chains can account for the high $\mathrm{Na}^{+}$fluxes since the induction of Heinz bodies in erythrocytes by acetylphenylhydrazine has been shown to selectively increase $\mathrm{K}^{+}$permeability with little effect on $\mathrm{Na}^{+}$movements (25). Even when the $\mathrm{K}^{+}$permeability of thalassemia minor erythrocytes is increased following metabolic depletion no change in $\mathrm{Na}^{+}$permeability occurs (26). Moreover, globin chain precipitation in thalassemics cannot explain the observed increase in the density of cation pumps in the erythrocyte. Whether globin chain precipitation contributed to the high $\mathrm{Na}^{+}$ influx in the single patient postsplenectomy (F.L.) also is uncertain since many erythroblasts were present in this cell suspension and it is likely that these cells have high cation permeability. Finally CDA type 2 erythrocytes which contain no free globin chains show increased $\mathrm{Na}^{+}$and $\mathrm{Ca}^{2+}$ fluxes of magnitude similar to thalassemia major.

The most likely explanation for the permeability changes derives from studies of the Ii-antigen system. Fetal erythrocytes possess i-antigen that is replaced after birth by the adult I-antigen. The finding of both $i$ and $I$ in adult thalassemic cells has led to the concept that the cell membrane is immature due to erythropoietic "stress" and skipped division of the marrow erythroblasts $(3,4)$. Immaturity of the cell membrane would also increase its cation permeability, a concept that has been documented for the human reticulocyte (10). Calcium uptake into thalassemic erythrocytes is increased by a mean 12 -fold while $\mathrm{Na}^{+}$influx by only fourfold above normal values, so that thalassemic erythrocytes have an increased ratio of $\mathrm{Ca}^{2+}: \mathrm{Na}^{+}$fluxes which is a feature of membrane immaturity also found in the human reticulocyte (10). Other evidence also supports the concept of membrane immaturity in thalassemic reticulocytes. Glucosamine is incorporated into the glycoprotein of reticulocyte stroma during short in vitro incubations and this incorporation is increased 5- to 10-fold in thalassemia over normal (27). However only those thalassemic patients showing evidence of erythropoietic "stress" (anemia; reticulocytes $>2 \%$; increased i-titers) show an increased membrane permeability to cations. Thus hypertransfused 
thalassemic patients with normal reticulocyte counts and no increase in i-titers have normal erythrocyte $\mathrm{Na}^{+}$permeability. ${ }^{2}$

Finally it can be predicted that conditions associated with shortened marrow erythroid transit times and i-antigen on the erythrocyte will be associated with increased $\mathrm{Na}^{+}, \mathrm{K}^{+}$, and $\mathrm{Ca}^{2+}$ permeability. The present study shows an increased $\mathrm{Na}^{+}$and $\mathrm{Ca}^{2+}$ permeability in CDA Type 2 erythrocytes with high titers of i-antigen obtained from a patient with a persistent anemia. Controversy exists over the etiology of increased $\mathrm{Na}^{+}$and $\mathrm{K}^{+}$fluxes and greater number of cation pumps per cell in $\mathrm{Rh}$ null disease $(28,29)$. Because this hemolytic condition is associated with increased titer of $i$-antigen, it seems likely that permeability changes result from membrane immaturity probably combined with the reticulocytosis (29). Thus a high cation permeability may be a marker of membrane immaturity not only in the thalassemic syndromes, but in other conditions of erythropoietic stress.

\section{ACKNOWLEDGMENTS}

This work owes much to the inspiration and encouragement of the late Miss Frances Lewis. The assistance of Drs. E. Schwartz, S. Friedman, Rae Matthews, D. Parkin, R. Lowenthal, and M. Davey in providing blood is gratefully acknowledged. We thank Mr. D. Ford for some i-antigen measurements. Mr. C. C. Shaller and Miss Kathy McCulloch provided expert technical assistance.

This study was supported by a grant from the National Health and Medical Research Council of Australia.

\section{REFERENCES}

1. Dacie, J. V. 1960. The haemolytic anaemias, congenital and acquired. Part 1. In The Congenital Anaemias. Grune \& Stratton, Inc., New York, 2nd edition. 200 pp.

2. Beutler, E. 1977. Osmotic fragility. In Hematology. W. J. Williams, E. Beutler, A. J. Erslev, and R. W. Rundles, editors. McGraw-Hill, Inc., New York. 2nd edition. $1609 \mathrm{pp}$.

3. Giblett, E. R., and M. C. Crookston. 1964. Agglutinability of red cells by anti-i in patients with thalassemia major and other haematological disorders. Nature (Lond.). 201: 1138-1139.

4. Hillman, R. S., and E. R. Giblett. 1965. Red cell membrane alteration associated with "marrow stress". J. Clin. Invest. 44: 1730-1736.

5. Nathan, D. G., T. B. Stossel, R. B. Gunn, H. S. Zarkowsky, and M. T. Laforet. 1969. Influence of hemoglobin precipitation on erythrocyte metabolism in alpha and beta thalassemia. J. Clin. Invest. 48: 33-41.

6. Schwartz, E. 1969. The silent carrier of beta thalassemia. N. Engl. J. Med. 281: 1327-1333.

7. Friedman, S., F. A. Oski, and E. Schwartz. 1972. Bone marrow and peripheral blood globin synthesis in an American black family with beta thalassemia. Blood. 39: 785-793.

8. Lowenthal, R. M., K. A. Marsden, C. L. Dewar, and G. R. Thompson. 1980. Congenital dyserythropoietic anaemia (CDA) with severe gout, rare Kell phenotype and erythrocyte, granulocyte and platelet membrane redupli-

\footnotetext{
${ }^{2}$ Wiley, J. S., K. McCulloch, D. Ford, and R. Matthews. Unpublished observations.
}

cation: a new variant of CDA Type II. Br. J. Haematol. 44: 211-220.

9. Marsh, W. L. 1972. Scoring of hemagglutination reactions. Transfusion. 12: 352-357.

10. Wiley, J. S., and C. C. Shaller. 1977. Selective loss of calcium permeability on maturation of reticulocytes. J. Clin. Invest. 59: 1113-1119.

11. Wiley, J. S., J. C. Ellory, M. A. Shuman, C. C. Shaller, and R. A. Cooper. 1975. Characteristics of the membrane defect in the hereditary stomatocytosis syndrome. Blood. 46: 337-356.

12. Lew, V. L. 1971. On the ATP dependence of the $\mathrm{Ca}^{2+}$ induced increase in $\mathrm{K}^{+}$permeability observed in human red cells. Biochim. Biophys. Acta. 233: 827-830.

13. Flatman, P. W., and V. L. Lew. 1977. Use of ionophore A23187 to measure and to control free and bound cytoplasmic $\mathrm{Mg}$ in intact red cells. Nature (Lond.). 267: 360-362.

14. Sarkadi, B., J. K. Alifimoff, R. B. Gunn, and D. C. Tosteson. 1978. Kinetics and stoichiometry of Na-dependent $\mathrm{Li}$ transport in human red blood cells. J. Gen. Physiol. 72: 249-265.

15. Wiley, J. S. 1972. Co-ordinated increase of sodium leak and sodium pump in hereditary spherocytosis. Br. J. Haematol. 22: 529-542.

16. Weiner, A. S., L. J. Unger, L. Cohen, and J. Feldman. 1956. Type specific cold auto-antibodies as a cause of acquired hemolytic anemia and hemolytic transfusion reactions: biologic test with bovine red cells. Ann. Intern. Med. 44: 221-240.

17. Wiley, J. S., and R. A. Cooper, 1974. A furosemide-sensitive cotransport of sodium plus potassium in the human red cell. J. Clin. Invest. 53: 745-755.

18. Schatzmann, H. J., and F. F. Vincenzi. 1969. Calcium movements across the membrane of human red cells. $J$. Physiol. (Lond.) 201: 369-395.

19. Schatzmann, H. J. 1973. Dependence on calcium concentration and stiochiometry of the calcium pump in human red cells. J. Physiol. (Lond.) 235: 551-569.

20. Ferreira, H. G., and V. L. Lew. 1976. Use of ionophore A23187 to measure cytoplasmic Ca buffering and activation of the Ca pump by internal Ca. Nature (Lond.). 259: $47-49$.

21. Sarkadi, B., I. Szasz, A. Gerloczy, and G. Gardos. 1977. Transport parameters and stoichiometry of active calcium ion extrusion in intact human red cells. Biochim. Biophys. Acta. 464: 93-107.

22. Sturgeon, P., and C. A. Finch. 1957. Erythrokinetics in Cooley's Anemia. Blood. 12: 64-71.

23. Vullo, C., and A. M. Tuniolo, 1958. Survival studies of thalassemic erythrocytes transfused into donors, into subjects with thalassemia minor and into normal and splenectomized subjects. Blood. 13: 803-811.

24. Hillcoat, B. L., and A. H. Waters. 1962. The survival of ${ }^{51}$ Cr-labelled autotransfused red cells in patients with thalassemia. Australasian Annals of Medicine. 11: 55-58.

25. Orringer, E. P., and J. C. Parker. 1977. Selective increase of potassium permeability in red blood cells exposed to acetylphenylhydrazine. Blood. 50: 1013-1021.

26. Gunn, R. B., D. N. Silvers, and W. F. Rosse. 1972. Potassium permeability in $\beta$-thalassemia minor red blood cells. J. Clin. Invest. 51: 1043-1050.

27. Eylar, E. H., and G. T. Matioli. 1965. Glycoprotein biosynthesis in human reticulocytes: a lesion in thalassemia. Science (Wash. D. C.). 147: 869-870.

28. Lauf, P. K., and C. H. Joiner. 1976. Increased potassium transport and ouabain binding in human Rh null red blood cells. Blood. 48: 457-468.

29. Wiley, J. S. 1978. Cation fluxes in Rh null red cells. Blood. 51: $555-556$ 